\title{
Examining the Implications of Massification of Education on Quality Assurance and Assessment in Higher Institutions in Lesotho
}

\author{
Neo Tlali', Tawanda Mukurunge ${ }^{1}$, Takura Bhila ${ }^{2}$ \\ 1,2Senior Lecturer and Academic Researcher, \\ ${ }^{1}$ Faculty of Communication and Media, ${ }^{2}$ Faculty of Information and Communication Technology \\ 1,2Limkokwing University of Creative Technology, Maseru, Lesotho
}

\begin{abstract}
How to cite this paper: Neo Tlali | Tawanda Mukurunge | Takura Bhila "Examining the Implications of Massification of Education on Quality Assurance and Assessment in Higher Institutions in Lesotho" Published in International Journal of Trend in Scientific Research and Development (ijtsrd), ISSN: 24566470, Volume-3 | Issue-3, April 2019, pp.1561-1568, URL: https://www.ijtsrd.c om/papers/ijtsrd23 493.pdf

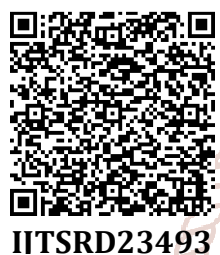

Copyright (C) 2019 by author(s) and International Journal of Trend in Scientific Research and Development Journal. This is an Open Access article distributed under the terms of the Creative Commons

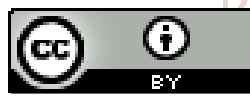
Attribution License (CC BY 4.0) (http://creativecommons.org/licenses/ by/4.0)

\section{ABSTRACT}

In recent years, we have witnessed rapid growth of tertiary institutions in Africa and this expansion has led to the massification and privatization of higher education. "Massification has been defined as the mass adaptation of a phenomenon by the suppression of its distinguishing features". Scott (1995) "used the term massification in the context of higher education (HE) systems to describe the rapid increase in student enrolment in the latter part of the twentieth century". Lesotho has not been spared from this system and there has been growth of various higher institutions in the country mainly privately owned. Students have been enrolled in huge numbers in these institutions and this has resulted in large numbers of students and shrinking number of lecturers leading to disproportional ratios of lecturers to students. Students joining these institutions are faced with various challenges emanating from lack of resources, congestion, alienation and subsequent workload for academic staff. Demands and challenges of massification in higher education have also seen academics with added responsibilities of diversifying to improve the quality of delivery with scant resources.

This paper explores the experiences and challenges faced by academics as well as students in higher institutions during this expansion era. Massification has been an issue of debate by both higher education researchers and policy-makers globally hence; the research intends to investigate how these policies have been addressed in other countries and how they can best be adopted to higher education in Lesotho. The study also attempts to learn about existing policies which are intended to revamp the quality of higher education, and or make considerable suggestions to higher education or how best quality can be maintained in the wake of massification. The study further hinges on the number of local higher learning centres institutions and the students enrolling in these establishments and how institutions ensure quality and proper assessment on learning, teaching and assessment.

KEYWORDS: higher education, massification, institutions, quality, assessment

\section{INTRODUCTION}

This research intends to carry out an exploratory and descriptive approach. These research methods are considered appropriate in this study as the researcher hopes they will assist in coming up with factors influencing the massification of education in Lesotho from the population that the researcher will select. These methods were also chosen because of their ability to gauge opinions and views of various stakeholders on this matter and possible solutions that can be adopted to address this situation. The population for this study will be educationists, students, and policy makers and this will be sampled. Institutions of higher learning will also form part of this study and thus Limkokwing University of Creative Techonology, Lesotho College of Education, National University of Lesotho and
Lerotholi Polytechnic will be part of this study. This population is relevant for this study because the researcher is of the view that their opinions can shed light in addressing the questions under study and because they are key players in the education sector. To select the above population; purposive sampling, stratified and cluster sampling will be employed. It is important to clarify why certain methods are used instead of others so that data is obtained from appropriate population. Therefore purposive sampling will be used to select educationists and policy makers while cluster sampling will be applied in selecting students at institutions of higher learning. Through these two sampling techniques the researcher hopes that an appropriate and good representation of the population will be achieved. 
Face to face interviews will be adopted as data collection methods for this research. These interviews will be carried out with educationists in higher education institutions (HEI's). The data for this study will be analysed qualitatively through themes that will be created by the researcher from the data.

\section{Background of study}

"Lesotho is a small, mountainous country completely surrounded by the Republic of South Africa". Lekhetho (2013) writes that Lesotho has got a population of about 2.2 million people, it is ranked $158^{\text {th }}$ out of 186 countries in the category of low human developed countries when looking at the Human Development Index. The introduction of "Free Primary Education" (FPE) was therefore a timeous intervention as this afforded, "free and compulsory education to all children of school going age irrespective of the socio- economic status of their parents", (Lekhetho, 2013).

The country implemented the FPE policy in its primary schools in the year 2000. Morojele (2012) says that Lesotho implemented this policy as part and parcel of the United Nations drive to avail "Education for All (EFA)" through the "Millennium Development Goals (MDGs)" to which Lesotho is a signatory. The actual sanction of compulsory free primary education took place in the year 2010 as the government made efforts to ensure "that all girls and boys of the age between 6 and 13 years attend school", (Morojele, 2012). The implementation of this policy saw many young children and those adults in their prime go to school. These massive enrolments in primary school led to many pupils being able to acquire secondary education. When the excitement of free education was still new and the education system adjusting to this new policy, another new policy was implemented by the Ministry of Education which abolished grade 7 examinations and subsequently the grading of High School leaving certificate. This means that the overwhelming majority of students from secondary schools are exerting pressure on higher education to expand.

\section{Introduction}

Higher Education Institutions (HEIs) in Lesotho have recently experienced, "rapid increase in student enrolment as a result of the free primary education programme". This has led to a large number of new students enrolling for learning at higher education institutions. The challenge has been that not all institutions can enrol all the students wishing to study due to lack of infrastructure, human resources and equipment required to address the learning and teaching needs of the students.

Free education provision at primary school and the low fees of M1200 per annum has made education affordable and accessible to any pupil willing to learn in primary and post primary school level. However, this supposedly positive development put a strain on tertiary institutions that are overwhelmed by the number of students willing to advance with their studies.

Lesotho has got only fourteen tertiary institutions of note and of those only three are universities. Of the three universities, only one, the National University of Lesotho, gets government subsidies and the other two Limkokwing
University of Creative Technology and Botho University are private institutions. These tertiary institutions do not have the capacity to service all aspiring graduates' needs.

The problem of massification in education is not peculiar to Lesotho alone as, Altbach, Reisberg and Rumbley (2009) write, "that participation in post compulsory education has expanded exponentially throughout the world during the last several decades". Altbach et al (2009) go on to document that, "globally, the percentage of the age cohort enrolled in tertiary education has grown from 19 percent in 2000 to 26 percent in 2007".

The paper's focal point is to critically study, "the impact of the massification of higher education on higher education institutions", and how this affects students as well as institutional concerns of quality and assessment. It also set out to examine whether massification affects institutions by creating more challenges for them or adds value to education.

\section{Statement of problem}

HEI's anywhere in the world are established to ensure that certain objectives are met. Mostly, these are ensuring that the country's economy is developed and that the country can compete with counterparts on every sector of national development. Thus these institutions' mandate is to make sure that they train human capital and provide skills that are relevant for the country to meet its set objectives. The government of Lesotho made strides in meeting the United Nations initiated National Strategic Development Goals of free provision of primary education as a human right but without making contingency plans for adequate provision of tertiary education to the same pupils. This has created constraints on tertiary institutions after being overwhelmed by masses of scholars seeking higher education. Higher institutions have not been capacitated to meet the massive enrolment of students from high school and this is compromising their higher education. While the numbers of students who enrol into higher institutions have risen, the infrastructure at higher institutions has remained under resourced. There are huge numbers of students in the classrooms and thus resulting in lecturers being overwhelmed with assignments to be assessed, contact with students reduced and overall quality assurance being compromised. As a result, this research undertakes to investigate challenges of massification and its impact on assessment and quality assurance.

\section{Aims of study}

This study sought to establish the challenges faced by institutions of higher learning in Lesotho emanating from massification of education and to find out what the stakeholders in the education sector are doing to address these challenges.

\section{Objectives of the study}

To establish the impact of massification of education at higher learning institutional level and the impact on quality assurance at institutions of higher learning.

To find out whether institutions of higher learning are sufficiently capacitated to accommodate increasing numbers of students applying for entry into these institutions. 


\section{Research questions}

1. How are tertiary institutions in Lesotho handling the influx of students seeking higher level education?

2. How can the imbalance of great numbers of students seeking entry into tertiary institutions in the face of inadequate human and material resources be addressed to the benefit of all?

3. How are institutions coping with the challenges of massive student enrolment and quality assurance in education in Lesotho?

\section{Justification}

The study strives to trigger consultations with various stakeholders in education and business to deliberate on possible solutions that can assist in addressing massification of education and its implications on higher institutions. This is a new study in Lesotho and hopefully it will contribute to existing literature on studies carried out elsewhere and find a way of how this can be meaningful to higher institutions in Lesotho in order to come up with explanations on the issues of quality assurance and assessment. It is the intention of this study to highlight challenges brought by massification in order to encourage higher learning institutions to continue playing their role of maintaining excellence and quality with whatever means of facilities, material and human resources available to them. The outcome of this study will further draw attention to "the implementation of free primary education" and check whether this has had an impact within the context of massification of education in higher learning institutions and effective ways that can be adopted to relook into the matter. It is the hope of the researchers that findings and possible recommendations of this study will lead to further engagements and consultations with various stakeholders in order to address massification. The paper recognises the need for institutions to expand in the wake of changing government policies to allow for qualifying students to be enrolled and be able to further their education.

\section{Theoretical Framework}

This study is supported by "Martin Trow's theory of Massification of higher education of 1971. The theory postulates that educational quality in higherinstitutionsoflearning is a compound concept of different factors. Its criterion is the unity of development, standardization, adaptation, serving and variety. During the period of higher education massification more people receivehighereducation therefore; there is a closer relationship between university components and the wider society. The theory further asserts that, with massification in higher education, the managements of universities no longer exist in isolation. This is because students, their parents and the society are involved in the evaluation of university education quality directly or indirectly. This in turn affects the day-today operations of the university. Therefore, thistheoryopinesthe need for continuous monitoring and evaluation of university education to ensure quality. According to this theory, the views, purposes, contents, structures, academic standards, functions, forms of establishing education, and management systems change tremendously with over-enrolment in universities. Although the postulations of this theory are mainly applicable to developed economies, it can, to a large extent, reflect the concept of massification in institutions of higher learning in developing economies as well".

\section{Literature Review}

Hornsby and Osman (2014) postulate that much as massification is viewed as advancing the course of "democratization of education and the social justice agenda in many countries", this however is hampered by the large quantities of students in class. Large populations in class are detrimental in many ways to student learning such as the inevitable compromise in quality as large classes correlate with low student performance (Hornsby and Osman, 2014).

Mohamedbhai (2008) identifies positive political economic implications of massification on African politics. Mohamedbhai (2008) cites the UNESCO 1999 writing that, "Significant increases in enrolment are a positive sign of democratization of access. Access to higher education is not only open to those with the class definition of student, that is, a person of 18- 24 years who has entered higher education directly from secondary school or soon thereafter, but is also available to older students who wish to further their education in this era of lifelong learning", (Mohamedbhai, 2008). This means that, "there are many more students of all ages, social class and caliber therefore massification is seen in appositive light because it is a proof of the democratization of access and is no longer elitist", (Mohamedbhai, 2008).

According to Kinyanjui, "for the last few decades, Kenya has experienced remarkable expansion of higher education", (Kinyanjui, 2007). "This has seen a major contribution to the development of human resources in Kenya. The current demand for expansion of higher education in Kenya is believed to result from the government policy which introduced free primary education in the year 2003. This consequently led to increase in the number of studentsjoining secondary schools", (Kinyajui, 2007). "Records from the Commission of HigherEducation(CHE)alsoindicate that thenumber ofstudentsobtaining theminimumqualificationforentrytouniversity ( $\mathrm{C}+$ and above) has increased".

Abagi \& Olweya (1999), on the other hand, argue that public universities have not been able to cope with these large numbers of students. Instructional materials have remained inadequate; lecture halls have been crowded, while the quality of academicstaff and pedagogical approaches at the institutions of higher learning has relatively declined. The doubleintakethat waseffected in theacademicyear 2011/2012 has raised a genuine debate as to the preparedness of the public universities", (Gudo, Olel \&Oanda, 2011).

"One of the major challenges that education policy formulators face is the creation of higher education system thatcombinesmassaccess with quality". Obanya (2004), "contends that massification of higher education resulting from having the academic gates widely open has brought about a myriad of challenges. These challenges range from quality, to judicious use of resources, the size of which has not matched the rate of increase in student numbers. Massification has led to lecturers handling large numbers of students. They have to expend much of their time marking scripts and carrying out regular assessments", as a result lecturer's will devote less time to research and upgrading themselves.

Goolam (2008) "contends that massification hasseriouseffecton teaching and leaming in higher education, but the situation in Africa is particularly grave. This is because of mismatch of increased enrolments and available academic facilities. There is an increase in student/teacher ratio leading to reduced individual attention to students. Africa is currently experiencing low levels of participation in research and also recording low research output". 
Mok and Jiang (2016), looking at the Chinese scenario, observe that, "the Chinese government has actively increased higher education opportunities in order to transform the country and prepare its people to cope with the growing challenges of the globalizing market. The massification of higher education has provided more and more access to junior colleges and universities, and subsequently produced a growing number of college graduates looking for jobs in the labour market", (Mok and Jiang, 2016). "College students have begun to doubt the effect of higher education massification on bringing more equality in admission and on improving their competitiveness in the job market and therefore, in turn, leads to widespread dissatisfaction with higher education development in China", (Mok and Jiang, 2016).

Underdal (2010) explores the issue of massification in education with the justification that the, "transition from 'elite' to 'mass' institutions has a wide range of implications and consequences for the universities involved, as well as for the societies they serve". Underdal (2010) defines 'elite' education as the, "proportion of cohorts (at most 15\%) for exclusive occupational roles involving membership of an informal 'ruling class'. 'mass' education is defined as the transmission of skills for a fairly broad range of technical or professional roles to a larger proportion of cohorts (between 16 and 50\%)", Underdal, (2010).

Ntim (2015) writes that the academic changes of the latter $20^{\text {th }}$ century as well as that of the early part $21^{\text {st }}$ century have precipitated a critical redesigning of the character of institutions of higher learning, especially the university across the globe. Citing the example of Ghana, Ntim (2015) says that massification has got quality assurance implications as setting standards and ensuring quality control becomes "especially problematic in the context of significant expansion and internationalization". Ntim (2015) continues to write that contemporary global ethics, regional integration and economic blocks in many continents, increasing awareness of partnership between institutions of higher learning and versatility due to increasing mobility of academics and students, etc. continue to precipitate the need for recognized international "benchmarks to guide comparison and evaluation of academic and professional qualifications".

Machingambi (2011) analyzing the South African higher education system, observes, "that access to higher education in that country is imperative after the demise of apartheid in a bid to redress the inequalities of the past". Machingambi (2011) goes on to say that "this is equal to saying that students of all races and social classes who participate in higher education should have equal chances of success in higher education so as to bring about social equity and equal educational opportunity in society". However, Machingambi (2011), "argues that while the issue of access to higher education is a necessary step towards social equity in South Africa, it is however not sufficient on its own to bring about this noble idea".

Akoojee and Nkomo (2007) writing about transformation and access of education in South Africa, say that "while there is clearly a need to enable access by improving student access (access with success), as opposed to simply ensuring their participation (access as participation), the adequacy of the initiatives needs to be evaluated in the context of institutional transformation. By introducing a quality assurance framework, institutions can ensure access initiatives are institutionalized", (Akoojee and Nkomo, 2007). Akoojee and Nkomo (2007) propose, "That a comprehensive quality assurance framework with embedded commitment to access is likely to respond appropriately to national development prerogatives of higher education access".

A pandemic "of enrolment explosion has aken place in recent years without commensurate growth in faculty members" (Secretary-General of AAU cited in Walshe, 2008).

\section{Methodology}

In this study exploratory and descriptive research were used. The "criteria for selecting a research design depended upon the appropriateness of the techniques for the objectives of the study", (Cohen, Manion \& Keith, 2000). The researcher intended to find out from the respondents how possible it is to maintain quality in the midst of massification of education in higher institutions in Lesotho. Thus the population's perceptions and opinions on this matter were relevant as the researcher hoped that it would help address the questions under study. The population for this study was three higher learning institutions. The sample for this population was comprised of institutions' administrators, lecturers, and experts in the field of Quality Assurance. This population was targeted because it was considered as key informed participants relevant to topic under study. Purposive and snowball sampling were employed in this study to select this population. Face to face interviews were conducted as well as telephonic interviews where necessary. The researcher employed interviews because they yielded in-depth data that was needed to address the questions under study. Researchers used face to face as well as telephonic interviews for data collection. Researchers chose this method basing themselves on Bryman (2004), "who states that, if one wants to understand peoples' world and their life she/he should talk with them". Moreover this method "allowed the researchers to enter into the other person's world, to understand the respondents' inner perspective and the meanings they make from those perspectives", (Mushi, 2002).

The study was analyzed qualitatively in textual demonstration. Researchers identified frequent subject matter and classifications that emerged from the data and these were grouped together. This assisted the researchers with identifying key concepts. Issues and ideas that appeared from this data were then summarized, analyzed and presented in text.

\section{Limitations}

This study would have been more detailed and elaborate if the researcher did not encounter resistance from fellow peers to provide information. Some institutions refused to be interviewed and give out information on the questions the researcher had provided and this led to this study falling short of crucial information. The researcher felt it was essential that information be provided so that challenges could be shared and discussed in order to allow for proper engagement and consultations between institutions in order to confront massification of education challenges collectively through shared knowledge. It is therefore demotivating when peers and relevant institutions withhold information for the purpose of research. 


\section{Results}

In the wake of massification of education in higher institutions resulting from large numbers of students from post secondary schools especially public schools running a free education, they have found it difficult to adjust and reform to afford everyone who qualifies entry into these institutions. Findings revealed that institutions have experienced a massive turnout of students applying to be enrolled for higher learning and thus have not been able to accommodate everyone. This has been caused by a number of factors, which generally are lack of facilities, insufficient manpower and lack of funding to run a number of courses to large cohorts.

Research findings indicate, amongst other factors, the increase in student numbers had compromised the education quality at higher institutions as lecturers struggle to deal with large numbers in terms of consultations, assessment and overall teaching and learning process. Lecturers were of the view that they cannot dictate to institutions management how many students should be enrolled as that is a process determined solely by management. With all HEI's aligning themselves with the quotas dictated by National Manpower Development Secretariat (Government Secretariat for Provision of Scholarships and Bursaries to Lesotho nationals studying locally and abroad) HEI's can also enroll students who are willing to pay for their education from personal funding. According to respondents massification of education has resulted in lecturers having more added responsibilities in order to improve student learning in the face of lack of resources to make the teaching and learning process better. Although higher institutions have tried to accommodate many students in various courses, it has been a challenge to accommodate everyone due to scarcity of resources and establishments especially in Information Technology, Engineering, Agricultural studies, Fashion and Apparel, Food and Nutrition, Nursing Science, Broadcasting and Film Studies etc, as these are the courses which demand a lot of specialized equipment. Institutions offering these courses have been experiencing paucity of resources prior to free education policy and not much have been achieved in recent years due to lack of funding. Some of these institutions find it difficult to admit any more students as their quality of education will be compromised as the expansion grows further. Higher institutions in the country are not adequately resourced for the current population of enrolled students and evidence is often clear in the extent to which lecturers struggle to meet deadlines for marks and attend to the curricular requirements of an increasingly diverse student population.

Institutions further showed that massification has also resulted with increasing workload for the academics and there seem to be no remedy for this. In some of these institutions academics have had to teach more courses due to lack of human resource and this has led to deteriorating attention to other areas of teaching and learning as well as support for students. Interviews revealed that this transition from free primary to abolition of High School leaving certificate has affected higher learning institutions negatively as they were not ready for massive applications for enrolment and thus could not develop their establishments for larger numbers of students timeously. Respondents were of the view that massification has a negative impact not only on increasing workload but on the capacity of lecturers needing more skills to handle large classrooms.

A local Quality Assurance Specialist indicated that there are massive challenges regarding engaging students in the kind of competencies required for the knowledge economy and supporting them in developing independent learning skills in the context of University's inability to provide resources for such engagement and assessing them in these extremely demanding assessment requirements.

The country, the findings revealed is not ready to develop education systems to address challenges of high applications turn out and enrolment. This is characterized by lack/less funding by the government, institutions inability to access grants and lack of human capital in academia. Interviews also showed that there is need for further research on how the country can address challenges of massification of education and these have to be critiqued constructively. They showed that policies have to be put in place by institutions of higher learning and this should be implemented after rigorous consultations with the government, private sector, business sector, academics, support at higher institutions, parents and students to find the lasting solutions to address these challenges. Interviewees highlighted the fact that massification of education remains a great concern to academia especially in quality of education. It was shown that lecturers are teaching huge classes which are becoming difficult to manage and teach thus resulting in quality compromise. Most lecturers indicated that they are not managing to provide students' feedback on time and thus students complain of late feedback that result in them not making necessary improvements on their work.

Libraries have also been affected by massification of education at institutions of higher learning. Increasingly large numbers of students are struggling to access required material to deal with assignments and tests due to insufficient books and other materials. Library representatives showed that due to expansion they have not been able to match increasing numbers of students with the required materials required by students and this means that other students wait for longer periods before accessing books that would have been borrowed by their peers. The introduction of e-library in some of these institutions has been solutions to certain extend to address lack of access in the traditional library; however facilities available are not enough to accommodate every student who may want to access information at a time convenient to them. They still have to wait for their peers to use computers while they wait for their turn.

Findings showed that there is uneven distribution of resources at higher institutions due to lack of funding. All the institutions depend on governments bursaries provided to students as well as subvention from the government for others. However, this is not enough to address the institutions' requirements. Interviews maintained that if higher institutions need to enroll more students, there is a need for partnership with the private sector or diversify their activities to include other money-making initiatives within teaching and learning in order to be able to survive with increasing numbers of students' year on year. It was also found out that there is a mismatch in numbers of students enrolling for higher learning institutions and 
available opportunities for employment in Lesotho. Interviews revealed that the main employer in Lesotho is the government, followed by the private sector which is also very stagnant in terms of growth in the country and thus increasing large numbers of students will not afford graduates to be absorbed by these limited employment sectors.

It was clear from the interviews that higher learning institutions in Lesotho are incapacitated to establish facilities to accommodate everyone and as the numbers of students enrolling in these institutions continue to rise, there will be further repercussions on quality assurance. Interviews also highlighted decline of relevant qualifications which has exacerbated the academic profession and it is under siege. Findings also indicated that highly qualified academic professionals continue to leave the country to other countries especially South Africa to look for better opportunities and this move is adding to already dwindling higher education academics.

\section{Discussion of findings}

From the findings, it emerged that there is tremendous pressure facing higher learning institutions in Lesotho and this needs urgent intervention from all stakeholders. The demand for H.E in Lesotho is increasing bringing an overwhelming mismatch with the higher institutions readiness for this expansion. Higher education institutions are facing challenges with large numbers of students' applications and subsequent admission due to inadequate resources. Already institutions are incapacitated to cater for current students due to limited resources and with massive students seeking admission this may pose even a bigger problem for local institutions. With policies and dynamics frequently being adopted in primary and post primary schools, higher learning institutions have to get ready for this transition and react accordingly to the large amounts of students wishing to be absorbed for higher education without compromising quality of education for these students. There is a clear insufficient infrastructure in the local institutions and this serves as a major obstacle to quality assurance. "Massification has led to lecturers handling large numbers of students. They have to expend much of their time marking scripts and carrying out regular assessments. As a result, devote less time to research". Goolam (2008) "contends that massification hasseriouseffecton teaching and learning in higher education, but the situation in Africa is particularly grave. This is because of mismatch of increased enrolments and available academic facilities".

Overcrowded classrooms, lack of resources, decreasing number of academic staff and low support for staff development are characterizing higher learning institutions and this calls for an urgent reaction to address these challenges. Polygreen (2007) is also of the view that teachers teaching large numbers of students have become so overstretched especially in the area of continuous assessment to monitor each individual student's learning progress but also can be exposed to fatigue related diseases. This view resonates with the finding that lecturers indicated that with growing numbers of students it has become overwhelmingly difficult for consultations with students as well as monitoring of students and it has impacted negatively on struggling students to be assisted on time. Adding to this concern are Albertyn et al., (2016) in Hornsby and Osman (2014). "The impact of massification on the quality of provision has also been a key concern. The very understanding of higher education quality has changed in order to better accommodate the changes underway. The most obvious of these have been concerned on how to teach the increasingly large classes, particularly at first-year undergraduate level, which mass higher education necessitates. Beyond the immediate classroom experience, this has raised more detailed questions about how to provide useful feedback on assessments" (Nicol, 2010) and "how the university library should respond" (Kanyengo, 2009).

Implementing new policies from primary and post primary has to be all inclusive as these institutions are correlated. All stakeholders in education should be consulted for policies discussions and engagements before implementation so that all stakeholders' views and opinions are tabled so that meaningful decisions could be made. It is clear that there is dissatisfaction on issues of policy as some of the respondents raised the issue that they are not consulted when policies are implemented and this needs to be improved in order to enhance everyone's participation. With existing masses already in primary and post primary schools, higher learning institutions are pressured to do crucial ramifications in their systems to accommodate these students. The findings showed that the numbers will continue to rise at public schools and it is up to higher institutions to work on their infrastructure to allow for all qualifying students to be admitted. "In much of the world, expansion of postsecondary education occurred without any serious planning or concern for the development of a logical or integrated "system" of postsecondary education", added Altbach et al (2017). Results show that free primary education and abolition of grading in high school has resulted not only in many learner's qualifying for entry into higher education, but also in a wider variety of students with varying competencies gaining access to institutions and programmes that were previously exclusive for their selection. With inadequate preparation for higher education teachers to handle this high numbers of students, many inadequately prepared to enroll in the increasingly demanding higher education curriculum, many teachers are experiencing burnout and frustration. There is a need to develop framework for curriculum and policy change that ensures that higher education institutions are not only consulted, but are engaged in a meaningful manner to prepare themselves for the impending changes in the students enrolling. From the interviews it was discovered that NCDC/ECOL can make changes without adequate engagement of higher education institutions and investment to come with the changes. This is indicative of lack of consultations between post primary management, ministry of education and higher education institutions thus there is a need for collaboration between all these stakeholders so that challenges leading to massification of education are addressed and that higher education institutions prepare in advance in terms of capacity in terms of physical and human resources to address problems associated with massification.

However in universities such as NUL these challenges are being addressed to a certain extent. There is a move towards virtual delivery and some of these institutions have invested in their own learning management systems such as Google Classroom and Thuto which enables reaching many students with limited face to face engagement. However, investment in material resources is essential, particularly network and 
capacity to utilize these tools. This shows a move in the right direction for these institutions in terms of reaching a large number of students at once without face to face interaction in the classrooms.

Professor Sejanamane in the Post newspaper article in April 2018 argues that when the government adopted the free primary education model, it failed to put in place adequate instrastructure to combat the increasing numbers of students who would enroll in high schools and tertiary institutions. Free primary education according to him was seen as an end in itself and the attrition rate was horrendous. He goes on to argue "you bring in these masses where there is no infrastructural investment. When the kids get to university you are then expected to teach crowds without the necessary infrastructure". He stated that the sad result of this massification is that there is no individual attention and there is no investment in technology and you have a demoralized workforce who is not keen to do things they are supposed to do. He argues that this massification of education has affected the quality of education at the university level. Professor Sejanamane is of the view that while other countries such as Rwanda are pushing technology in education, Lesotho is still stuck in promoting a system that encourages rote learning. (Gibbons 1998, Bennich 1997) agrees that massification poses numerous consequences on higher education not only through the increase of students but the accompanying change in the composition This view from Professor Sejanamane could not be far from the truth. It is significant that the government should have roped in higher learning institutions as well as industry people before implementing these policies so that different points of views are considered to come up with all encompassing policies and to allow for higher institutions to develop their resources in terms of funding, human capital and infrastructure. At this level of education, a student has to get the best form of quality of education as higher education prepares them to compete in the world of employment and with declining standards of quality offered as a result of massification, this quality cannot be guaranteed. Already in Lesotho there are limited higher institutions however there is not much that differentiates systems of these institutions from one another other. These systems are key to being classified to allow for suitable and relevant systems for quality assurance. Goolam (2008) "contends that massification has serious effects on teaching and learning in higher education, but the situation in Africa is particularly grave. This is because of mismatch of increased enrolments and available academic facilities".

An urgent need of expansion on higher institutions systems is required to address massification as all respondents believed that they still view higher education as a prerequisite to economic growth and that all barriers should be tackled. As higher institutions expand we should begin to rethink operational practices to be adopted while at the same time making sure that quality of education is not compromised. "It is important to note that in higher education, quality of students admitted to a university is a significant quality assurance ingredient at regulatory level". This means that there are still crucial factors to be looked into to address issues of strained facilities and resources in order to ensure quality provision of services at higher institutions. From the respondents' point of view, all alternatives to address this challenge point towards enabling institutions to invest in capital projects beyond just recurrent expenditure, so that innovations in technology and expansion of infrastructure to cope with large numbers even in the event of declining academics.

\section{Recommendations}

$>$ It is recommended that in order for higher institutions to address massification challenges, there should be design of online courses that will assist with reducing student numbers on campus by offering some of the qualifications online in order to maintain quality assurance, this means putting mechanisms in place to be able to offer online learning.

$>$ Consultations are crucial with all education stakeholders to participate on policy formulation so that all areas are covered from different sectors to deal with massification

$>$ Traditional methods of teaching and learning while they remain in practice and relevant should be improved by putting in place e-learning methods to avoid overcrowding in classrooms while prioritizing quality assurance.

$>$ At the helm of capacitating higher learning institutions is establishment of sufficient infrastructure, support of human capital as well as diversified funding to enable massive students enrolment, and provision of effective teaching and learning.

It is crucial that higher learning institutions address these challenges in order to minimize overload faced by lecturing staff so as to ensure provision of quality education and ensure quality of delivery.

\section{Conclusion}

From the results of this study it is apparent that the expansion of H.E has led to tremendous pressure on institutions of higher learning to respond as most of young people leaving post secondary schools wish to enroll in these institutions. As massive students continue to enroll into higher learning the capacity to absorb them has remained insufficient to meet this demand. This is a key concern for institutions to address. Major shifts into the operational systems of the institutions are crucial to ensure quality assurance which is a main priority of any educational institution. Support for teaching and learning is essential in form of staff development and retention of existing human capital as well as facilities in order to address massification. Higher learning institutions should also diversify their operations to adopt other funding initiatives to make expansion possible. Depending on the government scholarships to maintain operations in these institutions will not suffice going forward. Various institutions in the country should introspect and define their own challenges without looking at what others are doing to address the complexities resulting from massification of education as these will independently allow each and every institution internalize its own challenges and come up with long term resolutions. An all inclusive participation on educational policies is necessary to engage in harmonious discussions for the interest of the students at higher learning institutions. Higher education massification in Lesotho directs stakeholders to implement new reforms that will assist in enhancing quality of education that will be beneficial to students amidst huge enrollment at higher institutions.

\section{References}

[1] Abagi (2007) Kenya: University expansion has become a big joke. Daily Nation. Nairobi Nation Media 
[2] Akoojee, S. \& Nkomo, M. (2007). Access and quality in South African higher education: the twin challenges of transformation. SAJHE 21(3).

[3] Altbach, P. G., Reisberg, R. \& Rumbley, L. E. (2009). Trends in global higher education: Tracking an academic revolution. A Report Prepared for the UNESCO 2009 World Conference on Higher Education.

[4] Altbach, P. G., Reisberg, L. \& de Wit, H. (2017) Responding to Massification: Differentiation in Postsecondary Education Worldwide. Kober Foundation: Boston College Center for International Education

[5] Bennich, B. (1997) Organizing Innovative Research: The Inner life of University Departments (Issues in higher education). New York: IAU Press

[6] Gibbons, M. (1998). Higher Education Relevance in 21 st Century. Paper prepared for the WORLD Bank as part of its contribution to the UNESCO world Conference on higher education. Paris, 5-9 October 1998

[7] Goolam, M. (2008). The effects of Massification on higher education in Africa. A report by ADEA

[8] Hornsby, D.J. \& Osman, R. (2014). Massification in higher education: large classes. High Educ

[9] Lekhetho, M. (2013). The impact of free primary education in Lesotho. Int J Edn Sci, 5(4).

[10] Machingambi, S. (2011). Is access to higher education a sufficient condition for social equity in South Africa? A critical analysis. J Soc Sci, 28(1).
[11] Mohamedbhai, G. (2008). The effects of massification of higher education in Africa.

[12] Mok, K. H. \&Jiang, J. (2016). Massification of higher education: Challenges for admissions and graduate employment in China. Centre for Global Higher Education working paper series.

[13] Morojele, P. (2012). Implementing free primary education in Lesotho: Issues and challenges. J Soc Sci, 32(1).

[14] Ntim, S. (2015). Massification in Ghanaian higher education: Implications for pedagogical quality, equity control and assessment. International Research in Higher Education. Vol. 1.No. 1.

[15] Underdal, A. (2010). Implications of the change from elite to mass or multi- purpose institutions. The Authors Volume Compilation. Portland Press Limited.

[16] Massification in Ghanaian Higher Education: Implications for Pedagogical Quality, Equity Control and Assessment. Available from: https://www.researchgate.net/publication/29524202 8_Massification_in_Ghanaian_Higher_Education_Implica tions_for_Pedagogical_Quality_Equity_Control_and_Ass essment [Accessed Jul 14 2018].

[17] Polgreen, L. (2007). Africa storied colleges, jammed and crumbling in the New York Timer.

[18] Professor Sejanamane, The Post Newspaper article on Speaking Truth to Power, April 5-11 2018. Lesotho 